\title{
The role of organic cation transporter 2 inhibitor cimetidine, experimental diabetes mellitus and metformin on gabapentin pharmacokinetics in rats
}

\author{
Jhohann Richard de Lima Benzi ${ }^{\mathrm{a}}$, Priscila Akemi Yamamoto ${ }^{\mathrm{b}}$, Jessica Hanna Stevens ${ }^{\mathrm{b}}$, \\ Amanda Martins Baviera ${ }^{\mathrm{c}}$, Natália Valadares de Moraes ${ }^{\mathrm{b}, *}$

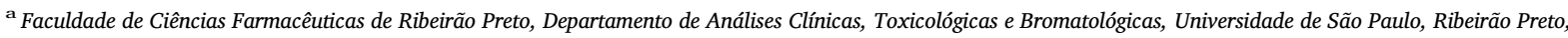 \\ SP, Brazil \\ ${ }^{\mathbf{b}}$ Faculdade de Ciências Farmacêuticas, Departamento de Princípios Ativos Naturais e Toxicologia, Universidade Estadual Paulista, Araraquara, SP, Brazil \\ ${ }^{\mathrm{c}}$ Faculdade de Ciências Farmacêuticas, Departamento de Análises Clínicas, Universidade Estadual Paulista, Araraquara, SP, Brazil
}

\section{A R T I C L E I N F O}

\section{Keywords:}

Oct2

Pharmacokinetics

Gabapentin

Diabetes mellitus

\begin{abstract}
A B S T R A C T
Purpose: We investigated the influence of diabetes mellitus (DM), glycemic control with insulin, cimetidine (Oct2 inhibitor) and metformin (Oct2 substrate) on the kinetic disposition of GAB in rats.

Main methods: Male Wistar rats were divided in five groups and all animals received an oral dose of $50 \mathrm{mg} / \mathrm{kg}$ GAB: (vehicle $+\mathrm{GAB}$ ), cimetidine + GAB (single dose of cimetidine [100 mg/kg] intraperitoneally $1 \mathrm{~h}$ before $\mathrm{GAB}$ ), metformin + GAB (single dose of metformin $100 \mathrm{mg} / \mathrm{kg}$ by gavage concomitantly with GAB), DM $+\mathrm{GAB}$ (single dose of $40 \mathrm{mg} / \mathrm{kg}$ streptozotocin (STZ) intravenously) and DM + GAB + insulin (single dose $40 \mathrm{mg} / \mathrm{kg}$ STZ intravenously and $2 \mathrm{IU}$ insulin twice daily for 15 days). Pharmacokinetic analysis was based on plasma and urine data concentrations.

Key findings: No differences in pharmacokinetic parameters were observed between vehicle $+\mathrm{GAB} \times$ cimetidine $+\mathrm{GAB}$ and vehicle $+\mathrm{GAB} \times$ metformin $+\mathrm{GAB}$ groups. Diabetes increased the fraction of GAB excreted unchanged in urine (vehicle + GAB: 0.48 [0.38-0.58]; DM + GAB: 0.83 [0.62-1.04]; $\mathrm{DM}+\mathrm{GAB}+$ insulin: 0.88 [0.77-0.93]) (mean [95\% confidence interval]) without any changes in GAB exposure. Insulin treated diabetic animals showed higher renal clearance compared to control (vehicle + GAB: 0.25 [0.18-0.30] L/h.kg; DM + GAB + insulin: 0.55 [0.45-1.43] L/h.kg), which was attributed to the diabetesinduced glomerular hyperfiltration.

Significance: Glomerular filtration is the main mechanism of renal excretion of GAB without significant contribution of Oct2 active transport.
\end{abstract}

\section{Introduction}

Gabapentin (GAB) is used to treat epilepsy, hot flashes, restless legs syndrome or neuropathic pain associated with cancer, postherpetic neuralgia or with diabetes [1-4]. GAB is not metabolized in rats or humans and the renal excretion is the main pathway of elimination [5]. Its renal excretion occurs by glomerular filtration and clinical data suggest the contribution by renal active secretion via organic cation transporter 2 (OCT2: humans; Oct2: rodents) [6-8]. However, drugdrug interactions and disease-drug interactions mediated by OCT2 were not extensively investigated for gabapentin up to date.

OCT2/Oct2 is expressed mainly in the kidneys, but it is also found in the placenta, thymus, adrenal gland and choroid plexus [9]. In mice, rats and humans, Oct2/OCT2 is expressed in the basolateral membrane of the proximal renal tubules [9-12]. This transporter plays a relevant role in the excretion of the endogenous substances dopamine, histamine, serotonin and drugs including, cetirizine, cimetidine, imipramine, lamivudine and cisplatin [9,12-14].

Cimetidine was characterized as an OCT2/Oct2 inhibitor drug by in vitro, in vivo, and clinical studies $[8,10,14,15]$ and there are no differences between human and rats in terms of the affinity of cimetidine for OCT2/Oct2 [16]. Cimetidine is recommended as OCT2/Oct2 inhibitor by The International Transporter Consortium, which developed organograms for drug-drug interaction studies [17]. Therefore, the investigation of the potential $\mathrm{GAB} \times$ cimetidine interaction will explain the impact of Oct2 activity on GAB pharmacokinetics.

Experimental diabetes mellitus (DM) is involved in several drug $\times$ disease interactions since it alters the gastrointestinal

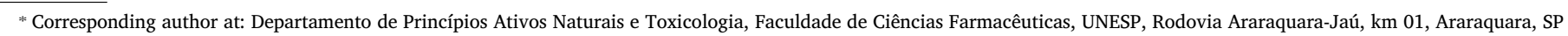
ZIP 14801-902, Brazil.

E-mail address: nmoraes@fcfar.unesp.br (N.V. de Moraes). 
absorption, distribution, metabolism and renal excretion of drugs [18]. In terms of P450 enzymes activity, experimental DM suppresses the expression of the isoforms CYP 1A2, 2C11, $2 \mathrm{C} 13$ and 3A2 and induces the expression of CYP 2A1, 2B1, 2C12, 4A1 and 2E1 [13,19,20]. DM also influences the activity of phase II enzymes [13] and drug transporters. A reduction of $50-70 \%$ reduction in Oct2 levels was observed in rats with DM induced by streptozotocin [21,22].

Metformin is considered the drug of choice for the treatment of DM type 2, due not only to glycemic control, but also to beneficial contributions related to vascular complications, body weight, lipid profile, diastolic pressure and reduced mortality [23]. OCT2 significantly contributed to renal excretion of metformin, as evidenced in clinical [24] and in vitro studies $[25,26]$. However, the influence of metformin on GAB kinetic disposition was not previously investigated.

Considering the potential role of OCT2/Oct2 in GAB kinetic disposition and the related effects of experimental DM on the expression of Oct2, the aims of the present work were: 1) to characterize the potential of Oct2 inhibition by cimetidine on GAB pharmacokinetics; 2) to evaluate the role of experimental DM and the glycemic control by insulin treatment on GAB pharmacokinetics; 3 ) to evaluate the impact of metformin on GAB pharmacokinetics. Therefore, an experimental study was conducted in rats treated with a single dose of GAB. Plasma and urine drug concentrations were evaluated for pharmacokinetic analysis.

\section{Materials and methods}

\subsection{Animals}

Male Wistar rats weighing approximately $250 \pm 20 \mathrm{~g}$ (7-8 weeks) were obtained from the Campus de Botucatu - Universidade Estadual Paulista and housed in controlled environmental conditions (temperature of $20 \pm 1{ }^{\circ} \mathrm{C}$ and humidity $60 \pm 20 \%$ ). The experimental protocols were approved by the Committee for Ethics in Animal Experimentation from the School of Pharmaceutical Sciences, UNESP, Araraquara, São Paulo (CEUA/FCF/Car n 75/2015).

\subsection{Induction of diabetes}

Diabetes mellitus was induced in 14-h fasting animals by a single intravenous dose of $40 \mathrm{mg} / \mathrm{kg}$ streptozotocin (STZ, > 98\%, Sigma Aldrich, St. Louis, MO, USA) dissolved in $0.1 \mathrm{M}$ sodium citrate buffer (pH 4.5) [30]. Four days after STZ administration, animals were considered diabetic if the glycemia values without fasting were higher than $300 \mathrm{mg} / \mathrm{dL}$ [31]. All non-diabetic groups received a volume of $0.2 \mathrm{~mL}$ of $0.01 \mathrm{M}$ citrate buffer solution $\mathrm{pH} 4.5$ at the same time as administration of STZ in the diabetic groups as a control of the vehicle.

\subsection{Experimental protocol}

The experiment involved a total of 105 animals divided in five groups (vehicle $+\mathrm{GAB}$, cimetidine $+\mathrm{GAB}$, metformin $+\mathrm{GAB}$, Experimental diabetes mellitus $(\mathrm{DM})+\mathrm{GAB}$ and $\mathrm{DM}+\mathrm{GAB}+$ insulin). Serial blood samples and urine collection were required for pharmacokinetic analysis of GAB. To minimize the contamination of the urine with blood, animals were maintained singly in metabolic cages for urine sampling. Each group had 21 animals, of which 15 were used for blood and 6 for urine sampling, in order to achieve $n=6$ per sampling time.

All animals received a single dose of $50 \mathrm{mg} / \mathrm{kg}$ GAB by gavage after 14-h fasting fifteen days after vehicle (citrate buffer) administration or diabetes confirmation. Cimetidine group received a single dose of $100 \mathrm{mg} / \mathrm{kg}$ cimetidine intraperitoneally, $60 \mathrm{~min}$ before receiving a single dose of GAB [14]. Metformin group animals receive a dose of $100 \mathrm{mg} / \mathrm{kg}$ metformin by gavage concomitantly with GAB dose [29]. Fifteen days after diabetes mellitus (DM) induction, DM + GAB group received $50 \mathrm{mg} / \mathrm{kg}$ GAB (gavage). $\mathrm{DM}+\mathrm{GAB}+$ insulin group was treated with 2 UI NPH insulin twice daily for fifteen days after diabetes induction and then received $50 \mathrm{mg} / \mathrm{kg}$ GAB (gavage).

Blood samples were obtained through circumcision of $0.3 \mathrm{~mm}$ of the tail distal end, after local heating at $42{ }^{\circ} \mathrm{C}$. Considering the total blood volume of animals and to avoid hypovolemic shock without fluid replacement, which could cause hemodilution $[27,28]$, the maximum of five blood collections of $500 \mu \mathrm{L}$ were drawn per animal. Individual blood samples were collected at times $0.25 \mathrm{~h} ; 0.5 \mathrm{~h} ; 0.75 \mathrm{~h} ; 1 \mathrm{~h} ; 2 \mathrm{~h} ; 3 \mathrm{~h}$; $4 \mathrm{~h} ; 5 \mathrm{~h} ; 6 \mathrm{~h} ; 8 \mathrm{~h} ; 10 \mathrm{~h} ; 12 \mathrm{~h}$ after GAB administration, in heparinized tubes. Thus, sparse blood samples were collected at predefined times randomly combined to reach the sample size of $6(n=6)$, per sampling time. Urine samples were collected at time intervals $0-4 \mathrm{~h} ; 4-8 \mathrm{~h}$; $8-12 \mathrm{~h}$. All samples were kept at $-70^{\circ} \mathrm{C}$ until analysis.

\subsection{Analysis of GAB in plasma by HPLC-MS and in urine by HPLC-UV}

The determination of GAB in rat plasma was performed by HPLC-MS (Perkin Elmer, Flexar SQ 300 MS, Shelton, USA). Phenacetin (SigmaAldrich, Missouri, USA) was used as internal standard (IS), at a concentration of $10 \mu \mathrm{g} / \mathrm{mL}$ in methanol. GAB and the IS were resolved on LiChrospher ${ }^{\circledast} \mathrm{C} 18 \mathrm{RP}$ column $(125 \times 4.0 \mathrm{~mm}, 5 \mu \mathrm{m}$, Merck, Darmstadt, Germany) kept at $18{ }^{\circ} \mathrm{C}$ and mobile phase consisting of $5 \mathrm{mM}$ ammonium acetate solution $(\mathrm{pH}=4)$ and methanol $(40: 60, \mathrm{v} / \mathrm{v})$ and flow rate of $0.4 \mathrm{~mL} / \mathrm{min}$ [32] The mass spectrometry was performed on positive ion mode and the protonated molecular ions $[\mathrm{M}-\mathrm{H}]^{+}$with $\mathrm{m} / \mathrm{z}$ 172 and 180 were used for monitoring GAB and IS, respectively. The determination of GAB in rat urine was performed by HPLC-UV at $\lambda=360 \mathrm{~nm}$. GAB and the IS (amlodipine besylate (99,7\%, European pharmacopeia Reference Standard, Sigma-Aldrich, São Paulo) at a concentration of $200 \mu \mathrm{g} / \mathrm{mL}$ in water, were resolved in the same column, and the mobile phase consisting of $0.05 \mathrm{M}$ sodium monobasic phosphate buffer ( $\mathrm{pH} 3.9)$ and methanol (27:73, v/v), in a flow rate of $1.2 \mathrm{~mL} / \mathrm{min}$.

Shortly, $100 \mu \mathrm{L}$ aliquots of plasma samples were added to $5 \mu \mathrm{L}$ of IS solution (phenacetin), $50 \mathrm{mg}$ of $\mathrm{Na}_{2} \mathrm{SO}_{4}$ and $1000 \mu \mathrm{L}$ of dichloromethane:n-butanol $(1: 1, \mathrm{v} / \mathrm{v})$ [33]. The microtubes were shaken and centrifuged $(15 \mathrm{~min}, 15,000 \times g$ ) and $900 \mu \mathrm{L}$ of the supernatant was separated and evaporated up to dryness. The residue was reconstituted in $120 \mu \mathrm{L}$ of mobile phase and $10 \mu \mathrm{L}$ was inject in the chromatographic system. Similarly, $100 \mu \mathrm{L}$ aliquots of urine samples were added to $30 \mu \mathrm{L}$ of IS solution (amlodipine), $50 \mathrm{mg}$ of $\mathrm{Na}_{2} \mathrm{SO}_{4}$ and $1000 \mu \mathrm{L}$ of dichloromethane:n-butanol $(1: 1, \mathrm{v} / \mathrm{v})$. The microtubes were shaken and centrifuged ( $15 \mathrm{~min}, 15,000 \times g$ ) and $800 \mu \mathrm{L}$ of the supernatant was separated and evaporated up to dryness. Aliquots of $40 \mu \mathrm{L}$ of borate buffer ( $\mathrm{pH}$ 8.2), $12 \mu \mathrm{L}$ of derivatization agent FDNB $0.06 \mathrm{M}$ and $400 \mu \mathrm{L}$ of acetonitrile [34] were added to the residues. After homogenization, the microtubes were heated at $65{ }^{\circ} \mathrm{C}$ for $10 \mathrm{~min}$ for derivatization reaction. After cool, $10 \mu \mathrm{L}$ of $1 \mathrm{M} \mathrm{HCl}$ were added and aliquots of $50 \mu \mathrm{L}$ were injected in the system.

\subsection{Pharmacokinetic and statistical analysis}

The areas under the plasma concentration versus time curves in the interval zero to infinity (AUC ${ }^{0-\infty}$ ) were calculated by Gauss-Laguerre Quadrature. The concentrations for the noncoincident times to the nodes of the quadrature were estimated by polynomial interpolation [35]. Differently from the trapezoidal rule, the Gauss-Laguerre Quadrature approach leads to more accurate results and its reliable in pharmacokinetics study designs when more than one sample (but not all of them) is taken from each animal $[35,36]$. The apparent total clearance $\left(\mathrm{CL}_{\mathrm{T}} / \mathrm{F}\right)$ was calculated using the equation $\mathrm{CL}_{\mathrm{T}} / \mathrm{F}=$ Dose/ $\mathrm{AUC}^{0-\infty}$. The maximum plasma concentrations $\left(\mathrm{C}_{\max }\right)$ and the time to reach maximum plasma concentrations $\left(\mathrm{T}_{\max }\right)$ were obtained from the observed data. Elimination half-life $\left(\mathrm{t}_{1 / 2}\right)$ was calculated by the equation: $\mathrm{t}_{1 / 2}=(0.693 \times \mathrm{Vd}) / \mathrm{Cl}_{\mathrm{T}} / \mathrm{F}$, were $\mathrm{Vd}$ is the apparent volume of distribution calculated as $\mathrm{C}_{\max } /$ dose. The fraction excreted unchanged in urine 
(Fe) was calculated using the equation: concentration excreted unchanged in urine $\times$ urine volume $(\mathrm{mL})$. The renal clearance $\left(\mathrm{Cl}_{\mathrm{r}}\right)$ was calculated by: $\mathrm{Fe} \times \mathrm{CL}_{\mathrm{T}} / \mathrm{F}$. The pharmacokinetic parameters were compared between groups using 95\% confidence intervals. Variances were estimated considering that some blood samples were collected from the same animal, but not for all sampling times, thus considering a sparse sampling [36-38].

\section{Results}

The methods for determination of $\mathrm{GAB}$ in plasma and urine were linear in the intervals $0.6-30 \mu \mathrm{g} / \mathrm{mL}$ and $3-30 \mu \mathrm{g} / \mathrm{mL}$, respectively. The relative standard deviation and the relative error of quality control samples did not exceed $15 \%$ for both biological matrices. GAB was determined in both plasma and urine samples up to $12 \mathrm{~h}$ after administration of $50 \mathrm{mg} / \mathrm{kg}$ in rats.

The STZ induced DM model resulted in only one rat that was not considered diabetic (glycemia values without fasting lower than $300 \mathrm{mg} / \mathrm{dL}$ ). On following days after the STZ dose, diabetic animals presented the classical signs of diabetes such as a lower rate of weight gain, a higher consumption of water and higher diuresis when compared with other groups (data not shown).

The administration of a single dose of $50 \mathrm{mg} / \mathrm{kg} \mathrm{GAB}$ in Wistar rats resulted in $\mathrm{AUC}^{0-\infty}, \mathrm{CL}_{\mathrm{T}} / \mathrm{F}$ and $\mathrm{t}_{1 / 2}$ values of $96.31 \pm 12.28 \mu \mathrm{g} \cdot \mathrm{h} / \mathrm{mL}$, $0.52 \pm 0.07 \mathrm{~L} / \mathrm{h} \cdot \mathrm{kg}$ and $2.72 \pm 0.37 \mathrm{~h}$, respectively. None of the animals presented ataxia or somnolence [38] after receiving $50 \mathrm{mg} / \mathrm{kg}$ $\mathrm{GAB}$. The pharmacokinetic parameters $\mathrm{AUC}^{0-\infty}, \mathrm{T}_{\max }, \mathrm{C}_{\max }, \mathrm{Cl}_{\mathrm{T}} / \mathrm{F}, \mathrm{t}_{1 / 2}$, $\mathrm{Cl}_{\mathrm{r}}$, and $\mathrm{Fe}$ were not changed after the administration of $\mathrm{GAB}$ and cimetidine or metformin (Figs. 1 and 2; Table 1).

The $\mathrm{DM}+\mathrm{GAB}$ group resulted in higher $\mathrm{Fe}$ when compared to vehicle + GAB group: $0.83 \pm 0.25 \quad(0.62-1.04) \times 0.48 \pm 0.13$ (0.38-0.58), respectively. $\mathrm{DM}+\mathrm{GAB}+$ insulin also resulted in higher Fe (0.85 \pm 0.10 [0.77-0.93]) and higher $\mathrm{Cl}_{\mathrm{r}}$ when compared to vehicle + GAB group: $0.55 \pm 0.10(0.45-1.43) \mathrm{L} / \mathrm{h} \cdot \mathrm{kg} \times 0.25 \pm 0.07$ (0.18-0.30) L/h.kg, respectively (Figs. 1 and 2; Table 1).
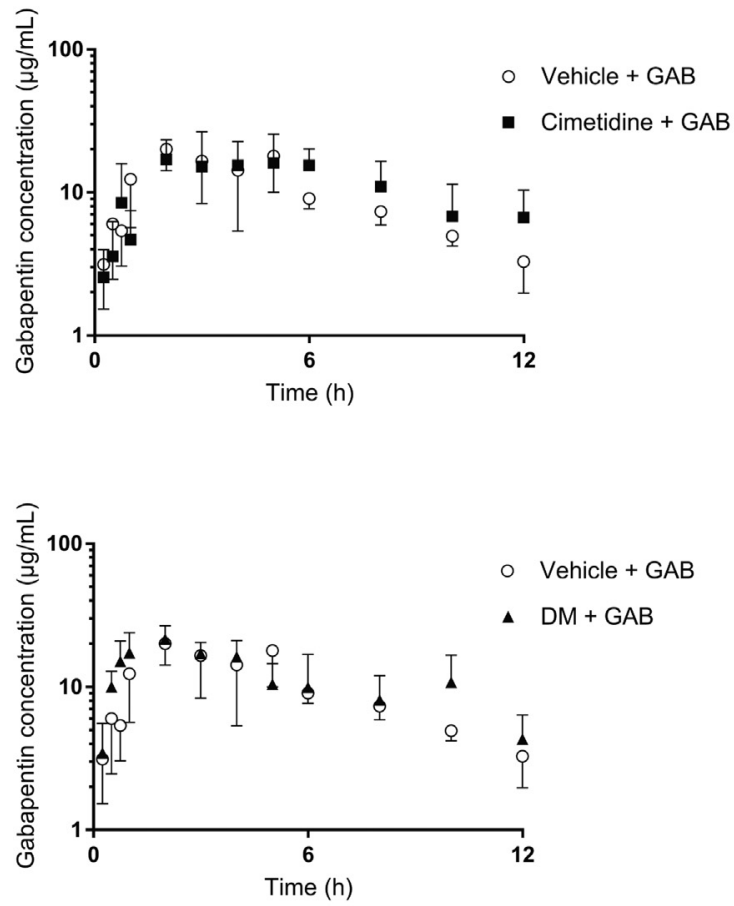

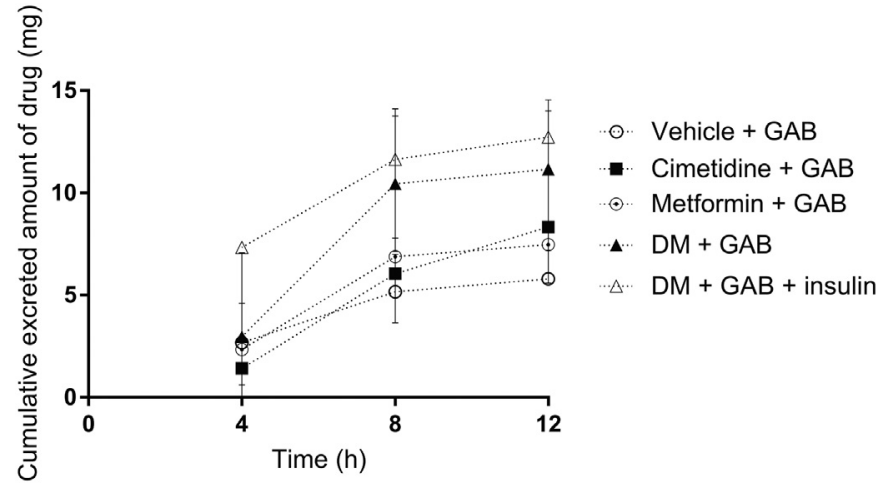

Fig. 2. Cumulative excreted amount of gabapentin $(\mathrm{GAB})$ in urine $(n=6)$, per sampling interval. Vehicle $+\mathrm{GAB}$ group was treated with $50 \mathrm{mg} / \mathrm{kg}$ GAB by gavage; cimetidine $+\mathrm{GAB}$ group received $100 \mathrm{mg} / \mathrm{kg}$ cimetidine intraperitoneally $60 \mathrm{~min}$ before a single dose of $50 \mathrm{mg} / \mathrm{kg} \mathrm{GAB}$ (gavage); metformin + GAB group was treated with $100 \mathrm{mg} / \mathrm{kg}$ metformin concomitantly with $50 \mathrm{mg} / \mathrm{kg}$ GAB (gavage). Fifteen days after diabetes mellitus (DM) induction, $\mathrm{DM}+\mathrm{GAB}$ group received $50 \mathrm{mg} / \mathrm{kg} \mathrm{GAB}$ (gavage); $\mathrm{DM}+\mathrm{GAB}+$ insulin group was treated with $2 \mathrm{UI} \mathrm{NPH}$ insulin twice daily for fifteen days after diabetes induction and then received $50 \mathrm{mg} / \mathrm{kg} \mathrm{GAB}$ (gavage).

\section{Discussion}

Several chromatographic methods for determination of GAB in biological fluids are described in the literature using high performance liquid chromatography with mass spectrometry, fluorescence or ultraviolet detection. Selective methods for determination of GAB in plasma and urine samples were validated with precision and accuracy at different concentration levels, no carry-over effect and acceptable stability of $\mathrm{GAB}$ in the tested conditions.

The present study describes the influence of cimetidine (Oct2 inhibitor), metformin (Oct2 substrate), DM and its glycemic control by insulin treatment on GAB kinetic disposition in male Wistar rats. The dose-independent $\mathrm{PK}$ parameters of $\mathrm{GAB}$ in vehicle + GAB group
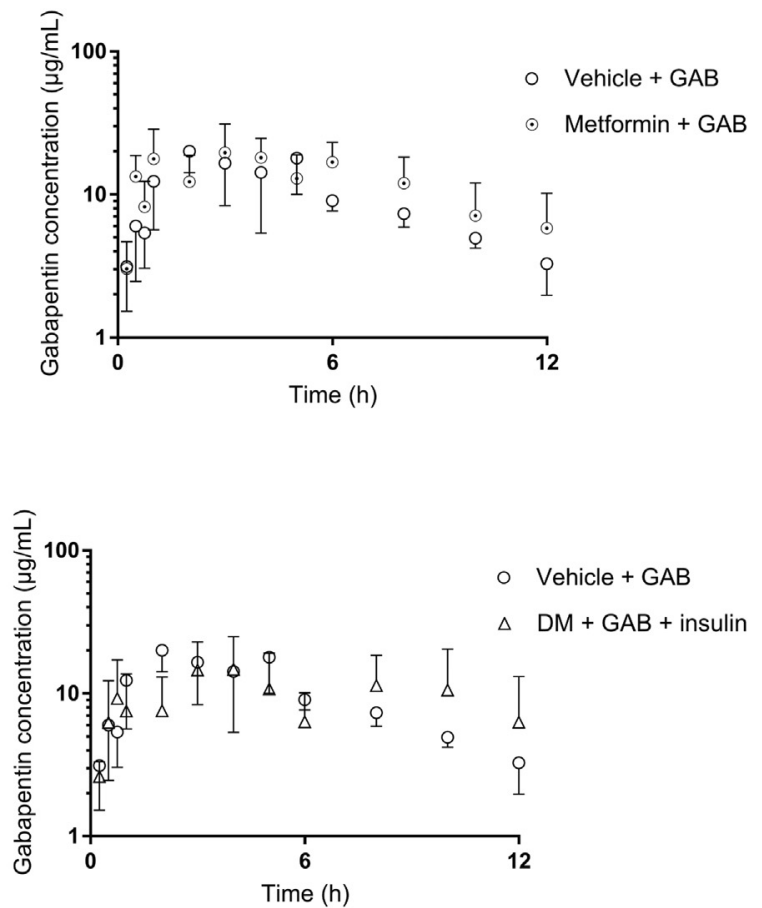

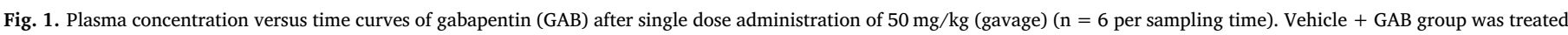

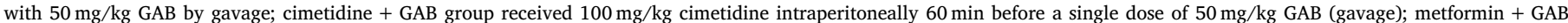

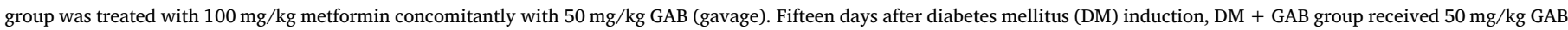
(gavage); $\mathrm{DM}+\mathrm{GAB}+$ insulin group was treated with $2 \mathrm{UI} \mathrm{NPH}$ insulin twice daily for fifteen days after diabetes induction and then received $50 \mathrm{mg} / \mathrm{kg}$ GAB (gavage). 
Table 1

Pharmacokinetic parameters of gabapentin after single dose of $50 \mathrm{mg} / \mathrm{kg}$ (gavage). Data expressed as mean \pm standard deviation (95\% confidence interval).

\begin{tabular}{|c|c|c|c|c|c|}
\hline & Vehicle + GAB & Cimetidine + GAB & Metformin + GAB & $\mathrm{DM}+\mathrm{GAB}$ & $\mathrm{DM}+$ Insulin + GAB \\
\hline $\begin{array}{l}\mathrm{AUC}^{0-\infty} \\
\qquad(\mu \mathrm{g} \cdot \mathrm{h} / \mathrm{mL})\end{array}$ & $\begin{array}{l}96.31 \pm 12.28 \\
(86.48-106.13)\end{array}$ & $\begin{array}{l}93.44 \pm 27.48 \\
(71.46-115.42)\end{array}$ & $\begin{array}{l}110.55 \pm 34.29 \\
(47.21-113.97)\end{array}$ & $\begin{array}{l}80.59 \pm 41.73 \\
(83.16-137.97)\end{array}$ & $\begin{array}{l}110.90 \pm 14.51 \\
(99.29-122.51)\end{array}$ \\
\hline $\begin{array}{l}\mathrm{C}_{\max } \\
\quad(\mu \mathrm{g} / \mathrm{mL})\end{array}$ & $\begin{array}{l}24.75 \pm 9.26 \\
(33.39-16.11)\end{array}$ & $\begin{array}{l}26.26 \pm 7.96 \\
(32.62-19.9)\end{array}$ & $\begin{array}{l}24.02 \pm 4.11 \\
(27.30-20.74)\end{array}$ & $\begin{array}{l}29.52 \pm 5.43 \\
(33.86-25.18)\end{array}$ & $\begin{array}{l}28.01 \pm 7.70 \\
(34.17-21.85)\end{array}$ \\
\hline $\mathrm{T}_{\max }(\mathrm{h})$ & $\begin{array}{l}3.66 \pm 1.11 \\
(2.77-4.54)\end{array}$ & $\begin{array}{l}4.16 \pm 1.34 \\
(3.08-5.23)\end{array}$ & $\begin{array}{l}2.95 \pm 1.49 \\
(1.25-3.32)\end{array}$ & $\begin{array}{l}2.95 \pm 1.49 \\
(1.75-4.14)\end{array}$ & $\begin{array}{l}4.83 \pm 2.27 \\
(3.01-6.64)\end{array}$ \\
\hline $\begin{array}{l}\mathrm{Cl}_{\mathrm{T}} / \mathrm{F} \\
\quad(\mathrm{L} / \mathrm{h} \cdot \mathrm{kg})\end{array}$ & $\begin{array}{l}0.52 \pm 0.07 \\
(0.46-0.57)\end{array}$ & $\begin{array}{l}0.54 \pm 0.12 \\
(0.44-0.63)\end{array}$ & $\begin{array}{l}0.45 \pm 0.17 \\
(0.31-0.58)\end{array}$ & $\begin{array}{l}0.62 \pm 6.77 \\
(-4.79-6.03)\end{array}$ & $\begin{array}{l}0.45 \pm 0.07 \\
(0.38-0.51)\end{array}$ \\
\hline $\mathrm{t}_{1 / 2}(\mathrm{~h})$ & $\begin{array}{l}2.72 \pm 0.37 \\
(2.30-3.14)\end{array}$ & $\begin{array}{l}2.52 \pm 0.22 \\
(2.26-2.77)\end{array}$ & $\begin{array}{l}2.87 \pm 0.48 \\
(2.32-3.42)\end{array}$ & $\begin{array}{l}3.18 \pm 0.83 \\
(2.23-4.14)\end{array}$ & $\begin{array}{l}1.99 \pm 1.03 \\
(0.56-3.42)\end{array}$ \\
\hline $\mathrm{Cl}_{\mathrm{r}} \quad(\mathrm{L} / \mathrm{h} \cdot \mathrm{kg})$ & $\begin{array}{l}0.25 \pm 0.07 \\
(0.18-0.30)\end{array}$ & $\begin{array}{l}0.34 \pm 0.10 \\
(0.28-0.43)\end{array}$ & $\begin{array}{l}0.36 \pm 0.12 \\
(0.28-0.47)\end{array}$ & $\begin{array}{l}0.55 \pm 0.10 \\
(0.45-1.43)^{*}\end{array}$ & $\begin{array}{l}0.27 \pm 0.04 \\
(0.24-0.30)\end{array}$ \\
\hline $\mathrm{Fe}$ & $\begin{array}{l}0.48 \pm 0.13 \\
(0.38-0.58)\end{array}$ & $\begin{array}{l}0.64 \pm 0.19 \\
(0.51-0.80)\end{array}$ & $\begin{array}{l}0.83 \pm 0.25 \\
(0.62-1.04)^{*}\end{array}$ & $\begin{array}{l}0.85 \pm 0.10 \\
(0.77-0.93)^{*}\end{array}$ & $\begin{array}{l}0.60 \pm 0.07 \\
(0.13-0.53)\end{array}$ \\
\hline
\end{tabular}

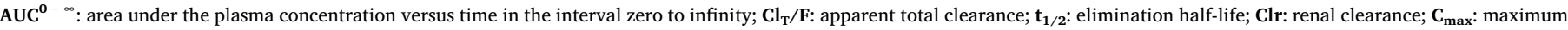
plasma concentrations; $\mathbf{T}_{\max }$ : times of maximum plasma concentrations; Fe: fraction excreted unchanged in urine.

* Statistical difference using 95\% confidence intervals in relation to vehicle + GAB.

(Table 1) were similar to previous studies in rats treated with $10-200 \mathrm{mg} / \mathrm{kg}$ doses [39,40,41]. Although, no differences were observed between gender on concentration/dose ratio of gabapentin in humans $[6,42]$, only male rats were investigated because the expression of rOCT2 mRNA and protein in the kidney of male rats were higher than those on females [43].

The pharmacokinetic parameters $\mathrm{AUC}^{0-\infty}, \mathrm{T}_{\max }, \mathrm{C}_{\max }, \mathrm{Cl}_{\mathrm{T}} / \mathrm{F}, \mathrm{t}_{1,2}$, $\mathrm{Cl}_{\mathrm{r}}$, and $\mathrm{Fe}$ were not changed after the coadministration of $\mathrm{GAB}$ and cimetidine, a known Oct2 inhibitor $[8,14,15,17]$ or the Oct2 substrate metformin [24,25]. Nadai et al., [14] used cimetidine to evaluate the contribution of Oct2 in the $\mathrm{Cl}_{\mathrm{r}}$ of 3-methylxanthine and enprofylline in rats. The use of $50 \mathrm{mg} / \mathrm{kg}$ and $100 \mathrm{mg} / \mathrm{kg}$ cimetidine intravenously did not change the glomerular filtration rate, but resulted in lower renal clearance of 3-methylxanthine and enprofylline, respectively. Intravenous doses of 25 to $100 \mathrm{mg} / \mathrm{kg}$ of cimetidine increased the $\mathrm{AUC}^{0-\infty}$ of guanfacine due to the reduced renal clearance in rats, which was attributed to the inhibition of renal tubular secretion mediated by Oct2 [15]. In a clinical study, Lal et al., [8] reported the interaction of $\mathrm{GAB}$ and cimetidine. Healthy volunteers were treated with daily doses of $1200 \mathrm{mg}$ of GAB enacarbil, a pro-drug of GAB, and four doses of $400 \mathrm{mg}$ of cimetidine for four days. Despite the decrease in $\mathrm{Cl}_{\mathrm{r}}$ by cimetidine and the resulting increase of $24 \%$ in the area under the plasma concentration versus time curve in equilibrium-state (AUC ${ }_{S S}$ ) of GAB, the authors suggest that these changes do not have any clinical relevance. The findings of our study corroborate the data observed [8], demonstrating that Oct2 inhibition by cimetidine does not significantly change the kinetic disposition of GAB.

Plasma blood glucose was measured in fasting and postprandial conditions in diabetic and nondiabetic rats. After 15 days of experiment, nondiabetic rats present fasting and postprandial glycemia values of 80-90 and 120-140 mg/dL, respectively. Diabetic animals (15 days post-STZ) usually have fasting and postprandial glycemia levels of 250-350 and 450-600 mg/dL, respectively. The impact of insulin on postprandial glycemia in diabetic animals is the normalization when 2IU/rat is administered two hours before blood collection with glycemia between 90 and $110 \mathrm{mg} / \mathrm{dL}$. Due to the risk of hypoglycemia, insulin was not administered to nondiabetic animals. The impact of metformin on postprandial glycemia in diabetic animals is milder and it does not affect serum insulin concentration in nondiabetic rats [44]. Several investigations of drug-drug interaction have used metformin in nondiabetic animals [29,45,46], even as multiple doses [29].

Down-regulation of Oct2 has been reported in STZ induced DM in rats $[21,22,47,48]$. Considering the progress of diabetes as an important aspect, the decline of Oct2 expression was rapid after induction of diabetes with around $50 \%$ reduction after 7 days of diabetes in rats
[22]. Although the STZ dose used in this study has been recognized as effective for DM establishment $[30,49]$ no differences were observed in GAB kinetic disposition in plasma after 15 days after diabetes induction. The higher amount of GAB excreted unchanged in urine in diabetes does not seem to have any relevant impact on GAB systemic exposure. Therefore, the absence of differences in PK parameters between both cimetidine $+\mathrm{GAB} \times$ vehicle $+\mathrm{GAB}$ and diabetes $\times$ vehicle $+\mathrm{GAB}$ suggests that Oct2 active transport is not relevant to GAB pharmacokinetics.

The increased $\mathrm{Fe}$ in $\mathrm{DM}+\mathrm{GAB}$ and in $\mathrm{DM}+\mathrm{GAB}+$ insulin groups and increased $\mathrm{Cl}_{\mathrm{r}}$ between vehicle $+\mathrm{GAB} \times \mathrm{DM}+\mathrm{GAB}+$ insulin could be explained by the glomerular hyperfiltration due the increased renal blood flow [50,51]. Phil et al. [51] investigated the renal hyperfiltration mechanisms in rats with DM and DM + insulin. The data showed that glomerular filtration and renal blood flow are enhanced in both groups. However, only in DM + insulin group a correlation between glomerular hyperfiltration and renal blood flow was observed $\left(\mathrm{R}^{2}: 0.81 ; \mathrm{P}<0.0001\right)$. This data corroborates the hypothesis that glomerular filtration is the major covariate on GAB kinetic disposition.

\section{Conclusion}

In summary, although Oct2 have been suggested to contribute to $\mathrm{GAB}$ renal excretion, our data shows that the Oct2 inhibitor cimetidine, the Oct2 substrate metformin and DM did not alter the kinetic disposition of GAB. Thus, the activity of Oct2 is not relevant to the kinetic disposition of $G A B$ in rats and glomerular filtration is the main renal excretion mechanism enrolled on GAB elimination without significant contribution of active processes.

\section{Acknowledgments}

This work was supported by Fundação de Amparo à Pesquisa do Estado de São Paulo (FAPESP: 2015/25728-2).

\section{Conflict of interest}

The authors declare that there are no conflicts of interest.

\section{References}

[1] M. Backonja, R.L. Glanzman, Gabapentin dosing for neuropathic pain: evidence from randomized, placebo-controlled clinical trials, Clin. Ther. 25 (2003) 81-104, http://dx.doi.org/10.1016/S0149-2918(03)90011-7.

[2] K.J. Pandya, G.R. Morrow, J.A. Roscoe, H. Zhao, J.T. Hickok, E. Pajon, T.J. Sweeney, T.K. Banerjee, P.J. Flynn, Gabapentin for hot flashes in 420 women with breast cancer: a randomised double-blind placebo-controlled trial, Lancet 366 
(2006) 818-824, http://dx.doi.org/10.1016/S0140-6736(05)67215-7.

[3] H.F. Miranda, V. Noriega, J.C. Prieto, P. Zanetta, R. Castillo, N. Aranda, F. Sierralta, Antinociceptive interaction of tramadol with gabapentin in experimental mononeuropathic pain, Basic Clin. Pharmacol. Toxicol. 119 (2016) 210-214, http://dx. doi.org/10.1111/bcpt.12567.

[4] H.I. Cheikh Hassan, F. Brennan, G. Collett, E.A. Josland, M.A. Brown, Efficacy and safety of gabapentin for uremic pruritus and restless legs syndrome in conservatively managed patients with chronic kidney disease, J. Pain Symptom Manag. 49 (2015) 782-789, http://dx.doi.org/10.1016/j.jpainsymman.2014.08.010.

[5] M.J. McLean, Gabapentin, Epilepsia 36 (1995) S73-S86, http://dx.doi.org/10. 1111/j.1528-1157.1995.tb06001.x.

[6] R.A. Boyd, D. Turck, R.B. Abel, T.J. Sedman, H.N. Bockbrader, Effects of age and gender on single-dose pharmacokinetics of gabapentin, Epilepsia 40 (1999) 474-479, http://dx.doi.org/10.1111/j.1528-1157.1999.tb00743.x.

[7] D. Ouellet, H.N. Bockbrader, D.L. Wesche, D.Y. Shapiro, E. Garofalo, Population pharmacokinetics of gabapentin in infants and children, Epilepsy Res. 47 (2001) 229-241, http://dx.doi.org/10.1016/S0920-1211(01)00311-4.

[8] R. Lal, J. Sukbuntherng, W. Luo, V. Vicente, R. Blumenthal, J. Ho, K.C. Cundy, Clinical pharmacokinetic drug interaction studies of gabapentin enacarbil, a novel transported prodrug of gabapentin, with naproxen and cimetidine, Br. J. Clin. Pharmacol. 69 (2010) 498-507, http://dx.doi.org/10.1111/j.1365-2125.2010. 03616.x.

[9] H. Koepsell, The SLC22 family with transporters of organic cations, anions and zwitterions, Mol. Asp. Med. 34 (2013) 413-435, http://dx.doi.org/10.1016/j.mam. 2012.10.010.

[10] Y. Urakami, M. Okuda, S. Masuda, H. Saito, K.-I. Inui, Functional characteristics and membrane localization of rat multispecific organic cation transporters, OCT1 and OCT2, mediating tubular secretion of cationic drugs, J. Pharmacol. Exp. Ther. 287 (1998) 800 LP-805 http://jpet.aspetjournals.org/content/287/2/800.abstract.

[11] U. Karbach, J. Kricke, F. Meyer-Wentrup, V. Gorboulev, C. Volk, D. Loffing-Cueni, B. Kaissling, S. Bachmann, H. Koepsell, Localization of organic cation transporters OCT1 and OCT2 in rat kidney, Am. J. Phys. Renal Phys. 279 (2000) F679-87 http:// www.ncbi.nlm.nih.gov/pubmed/10997918.

[12] M.J. Dresser, M.K. Leabman, K.M. Giacomini, Transporters involved $\mathrm{n}$ the elimination of drugs in the kidney: organic anion transporters and organic cation transporters, J. Pharm. Sci. 4 (90) (2001) 397-421, http://dx.doi.org/10.1021/ jm2001629.

[13] M. Dostalek, F. Akhlaghi, M. Puzanovova, Effect of diabetes mellitus on pharmacokinetic and pharmacodynamic properties of drugs, Clin. Pharmacokinet. 51 (2012) 481-499, http://dx.doi.org/10.2165/11631900-000000000-00000.

[14] M. Nadai, M. Kato, H. Yoshizumi, M. Kimura, S. Kurono, F. Abe, H. Saito, T. Hasegawa, Possible involvement of organic anion and cation transporters in renal excretion of xanthine derivatives, 3-methylxanthine and enprofylline, Life Sci. 81 (2007) 1175-1182, http://dx.doi.org/10.1016/j.lfs.2007.07.032.

[15] X. Li, X. Sun, J. Chen, Y. Lu, Y. Zhang, C. Wang, J. Li, Q. Zhang, D. Zhao, X. Chen, Investigation of the role of organic cation transporter 2 (OCT2) in the renal transport of guanfacine, a selective $\alpha 2 \mathrm{~A}$-adrenoreceptor agonist, Xenobiotica 45 (2015) 88-94, http://dx.doi.org/10.3109/00498254.2014.949904.

[16] K.I. Umehara, T. Iwatsubo, K. Noguchi, H. Kamimura, Functional involvement of the organic cation transporter 2 (rOct2) in the renal uptake of organic cations in rats, J. Int. Med. Res. 36 (2008) 123-136, http://dx.doi.org/10.1177/ 147323000803600116.

[17] I.T. Consortium, K. Giacomini, S.-M. Huang, D. Tweedie, L. Benet, K. Brouwer, X. Chu, A. Dahlin, R. Evers, V. Fischer, K. Hillgren, K. Hoffmaster, T. Ishikawa, D. Keppler, R. Kim, C. Lee, M. Niemi, J. Polli, Y. Sugiyama, P. Swaan, J. Ware, S. Wright, S. Yee, M. Zamek-Gliszczynski, L. Zhang, Membrane transporters in drug development, Nat. Rev. Drug Discov. 9 (2010) 215-236, http://dx.doi.org/10. 1038/nrd3028.

[18] M. Dostalek, F. Akhlaghi, M. Puzanovova, Effect of diabetes mellitus on pharmacokinetic and pharmacodynamic properties of drugs, Clin. Pharmacokinet. 5 (2012) 481-499, http://dx.doi.org/10.2165/11631900-000000000-00000.

[19] J.B. Schenkman, Induction of diabetes and evaluation of diabetic state on P450 expression, Methods Enzymol. 206 (1991) 325-331, http://dx.doi.org/10.1016/ 0076-6879(91)06102-9.

[20] H. Iber, T. Li-Masters, Q. Chen, S. Yu, E.T. Morgan, Regulation of hepatic cytochrome P450 2C11 via cAMP: implications for down-regulation in diabetes, fasting, and inflammation, J. Pharmacol. Exp. Ther. 297 (2001) 174-180.

[21] M.T. Nowicki, L.M. Aleksunes, S.P. Sawant, A.V. Dnyanmote, H.M. Mehendale, J.E. Manautou, Renal and hepatic transporter expression in type 2 diabetic rats, Drug Metab. Lett. 2 (2008) 11-17, http://dx.doi.org/10.2174/ 187231208783478425

[22] B. Grover, D. Buckley, A.R. Buckley, W. Cacini, Reduced expression of organic cation transporters rOCT1 and rOCT2 in experimental diabetes, J. Pharmacol. Exp. Ther. 308 (2004) 949-956, http://dx.doi.org/10.1124/jpet.103.058388.

[23] A. Saenz, I. Fenandez-Esteban, A. Mataix, M. Ausejo, M. Roque, D. Moher, Metformin monotherapy for type 2 diabetes mellitus, Cochrane Database Syst. Rev. 20 (3) (2005), http://dx.doi.org/10.1002/14651858.CD002966.pub3.

[24] H. Yoon, H.-Y. Cho, H.-D. Yoo, S.-M. Kim, Y.-B. Lee, Influences of organic cation transporter polymorphisms on the population pharmacokinetics of metformin in healthy subjects, AAPS J. 15 (2013) 571-580, http://dx.doi.org/10.1208/s12248013-9460-z.

[25] N. Kimura, S. Masuda, Y. Tanihara, H. Ueo, M. Okuda, T. Katsura, K.-I. Inui, Metformin is a superior substrate for renal organic cation transporter OCT2 rather than hepatic OCT1, Drug Metab. Pharmacokinet. 20 (2005) 379-386, http://dx.doi. org/10.2133/dmpk.20.379.

[26] I.S. Song, H.J. Shin, E.J. Shim, I.S. Jung, W.Y. Kim, J.H. Shon, J.G. Shin, Genetic variants of the organic cation transporter 2 influence the disposition of metformin, Clin. Pharmacol. Ther. 84 (2008) 559-562, http://dx.doi.org/10.1038/clpt. 2008.61.

[27] K.-H. Diehl, R. Hull, D. Morton, R. Pfister, Y. Rabemampianina, D. Smith, J. M. Vidal, C. Van De Vorstenbosch, A good practice guide to the administration of substances and removal of blood, including routes and volumes GOOD PRACTICE GUIDE FOR ADMINISTRATION OF SUBSTANCES, J. Appl. Toxicol. J. Appl. Toxicol. 21 (2001) 15-23, http://dx.doi.org/10.1002/jat.727.

[28] J. Ott Joslin, Blood collection techniques in exotic small mammals, J. Exot. Pet Med. 18 (2009) 117-139, http://dx.doi.org/10.1053/j.jepm.2009.04.002.

[29] Y. Ma, A. Shi, H. Qin, T. Zhang, Y. Wu, G. Zhang, X. Wu, Metoprolol decreases the plasma exposure of metformin via the induction of liver, kidney and muscle uptake in rats, Biopharm. Drug Dispos. 9 (37) (2016) 511-521, http://dx.doi.org/10.1002/ bdd.2041.

[30] C.A. Arcaro, V.O. Gutierres, R.P. Assis, T.F. Moreira, P.I. Costa, A.M. Baviera, I.L. Brunetti, Piperine, a natural bioenhancer, nullifies the antidiabetic and antioxidant activities of curcumin in streptozotocin-diabetic rats, PLoS One 9 (2014), http://dx.doi.org/10.1371/journal.pone.0113993.

[31] P. Trinder, Determination of blood glucose using 4-amino phenazone as oxygen acceptor, J. Clin. Pathol. 22 (1969) 246, http://dx.doi.org/10.1136/jcp.22.2.246-b.

[32] K.C. Carlsson, J.L.E. Reubsaet, Sample preparation and determination of gabapentin in venous and capillary blood using liquid chromatography-tandem mass spectrometry, J. Pharm. Biomed. Anal. 34 (2004) 415-423, http://dx.doi.org/10.1016/ S0731-7085(03)00572-7.

[33] G. Bahrami, A. Kiani, Sensitive high-performance liquid chromatographic quantitation of gabapentin in human serum using liquid-liquid extraction and pre-column derivatization with 9-fluorenylmethyl chloroformate, J. Chromatogr. B Anal. Technol. Biomed. Life Sci. 835 (2006) 123-126, http://dx.doi.org/10.1016/j. jchromb.2006.03.011.

[34] H. Jalalizadeh, E. Souri, M.B. Tehrani, A. Jahangiri, Validated HPLC method for the determination of gabapentin in human plasma using pre-column derivatization with 1-fluoro-2,4-dinitrobenzene and its application to a pharmacokinetic study, J. Chromatogr. B Anal. Technol. Biomed. Life Sci. 854 (2007) 43-47, http://dx.doi. org/10.1016/j.jchromb.2007.03.039.

[35] T. Amisaki, Gaussian quadrature as a numerical integration method for estimating area under the curve, Biol. Pharm. Bull. 24 (2001) 70-77 http://www.ncbi.nlm.nih. gov/pubmed/21728688.

[36] C. Navarro-Fontestad, I. González-Álvarez, C. Fernández-Teruel, M. Bermejo, V.G. Casabõ, A new mathematical approach for the estimation of the AUC and its variability under different experimental designs in preclinical studies, Pharm. Stat. 11 (2012) 14-23, http://dx.doi.org/10.1002/pst.484.

[37] M. Mauro, J.S. Lepera, B. Borsari, J.M.V. Capela, N.V. de Moraes, Effect of inhalation exposure to toluene on the activity of organic anion transporting polypeptide (Oatp) using pravastatin as a probe drug in rats, Xenobiotica 0 (2017) 1-5, http://dx.doi.org/10.1080/00498254.2017.1353717.

[38] J.M.V. Capela, M.V. Capela, J.S. Lepera, Estimação da área sob a curva para dados farmacocinéticos obtidos por amostragem esparsa, $34^{\circ}$ Congresso Nacional de Matemática Aplicada e Computacional, Águas de Lindóia, 2012.

[39] A. Folkesson, P.H. Honoré, O.J. Bjerrum, Co-administered gabapentin and venlafaxine in nerve injured rats: effect on mechanical hypersensitivity, motor function and pharmacokinetics, Scand J Pain 1 (2010) 91-97, http://dx.doi.org/10.1016/j. sjpain.2009.12.001.

[40] L.L. Radulovic, D. Türck, A. von Hodenberg, K.O. Vollmer, W.P. McNally, P.D. DeHart, B.J. Hanson, H.N. Bockbrader, T. Chang, Disposition of gabapentin (neurontin) in mice, rats, dogs, and monkeys, Drug Metab. Dispos. 23 (1995) 441 LP-448 http://dmd.aspetjournals.org/content/23/4/441.abstract.

[41] M.S. Larsen, S. Frølund, M.K. Nøhr, C.U. Nielsen, M. Garmer, M. Kreilgaard, R. Holm, In vivo and in vitro evaluations of intestinal gabapentin absorption: effect of dose and inhibitors on carrier-mediated transport, Pharm. Res. 32 (2013) 898-909, http://dx.doi.org/10.1007/s11095-014-1505-1.

[42] C. Johannessen Landmark, G. Beiske, A. Baftiu, M.L. Burns, S.I. Johannessen, Experience from therapeutic drug monitoring and gender aspects of gabapentin and pregabalin in clinical practice, Seizure 28 (2015) 88-91, http://dx.doi.org/10. 1016/j.seizure.2015.02.017

[43] Y. Urakami, N. Nakamura, K. Takahashi, M. Okuda, H. Saito, Y. Hashimoto, K. Inui, Gender differences in expression of organic cation transporter OCT2 in rat kidney, FEBS Lett. 461 (1999) 339-342, http://dx.doi.org/10.1016/S0014-5793(99) 01491-X.

[44] C.T. Musabayane, P.T. Bwititi, J.A. Ojewole, Effects of oral administration of some herbal extracts on food consumption and blood glucose levels in normal and streptozotocin-treated diabetic rats, Methods Find. Exp. Clin. Pharmacol. 28 (2006) 223-228.

[45] Y.H. Choi, S.G. Kim, M.G. Lee, Dose-independent pharmacokinetics of metformin in rats: hepatic and gastrointestinal first-pass effects, J. Pharm. Sci. 95 (2006) 2543-2552, http://dx.doi.org/10.1002/jps.20744.

[46] R.Q. Gabr, A.A. El-Sherbeni, M. Ben-Eltriki, A.O. El-Kadi, D.R. Brocks, Pharmacokinetics of metformin in the rat: assessment of the effect of hyperlipidemia and evidence for its metabolism to guanylurea, Can. J. Physiol. Pharmacol. 95 (2017) 530-538, http://dx.doi.org/10.2135/cropsci2013.11.0764.

[47] M.C. Thomas, C. Tikellis, W.C. Burns, V. Thallas, J.M. Forbes, Z. Cao, T.M. Osicka, L.M. Russo, G. Jerums, H. Ghabrial, M.E. Cooper, P. Kantharidis, Reduced tubula cation transport in diabetes: prevented by ACE inhibition, Kidney Int. 63 (2003) 2152-2161, http://dx.doi.org/10.1046/j.1523-1755.2003.00006.x.

[48] M.C. Thomas, C. Tikellis, P. Kantharidis, W.C. Burns, M.E. Cooper, J.M. Forbes, The role of advanced glycation in reduced organic cation transport associated with experimental, Diabetes 311 (2004) 456-466, http://dx.doi.org/10.1124/jpet.104. 
070672.influencing.

[49] M. Radenković, M. Stojanović, M. Prostran, Experimental diabetes induced by alloxan and streptozotocin: the current state of the art, J. Pharmacol. Toxicol.

Methods 78 (2016) 13-31, http://dx.doi.org/10.1016/j.vascn.2015.11.004.

[50] P. Iglesias, J.J. Díez, Insulin therapy in renal disease, Diabetes. Obes. Metab. 10
(2008) 811-823, http://dx.doi.org/10.1111/j.1463-1326.2007.00802.x.

[51] L. Pihl, P. Persson, A. Fasching, P. Hansell, G.F. DiBona, F. Palm, Insulin induces the correlation between renal blood flow and glomerular filtration rate in diabetes: implications for mechanisms causing hyperfiltration, AJP Regul. Integr. Comp. Physiol. 303 (2012) R39-R47, http://dx.doi.org/10.1152/ajpregu.00582.2011. 